\title{
A Significant association between CXCL10 -1447 $A>G$ and IL18 -607 C>A gene polymorphisms with Human T-cell lymphotropic virus type 1 Associated Myelopathy/Tropical Spastic Paraparesis (HAM- TSP), a case-control report from city of Mashhad, Iran
}

Houshang Rafatpanah

Mashhad University of Medical Sciences

Zohreh Poursina

Mashhad University of Medical Sciences

Hadi Zare Marzouni

Mashhad University of Medical Sciences

Mahdi Atabaki

Mashhad University of Medical Sciences https://orcid.org/0000-0002-8642-292X

Reza Farid-Hosseini

Mashhad University of Medical Sciences

Jalil Tavakkol-Afshari

Mashhad University of Medical Sciences

Mojgan Mohammadi ( $\nabla$ mozhganmohammadi69@yahoo.co.uk)

Mashhad University of Medical Sciences https://orcid.org/0000-0002-0088-5916

Research

Keywords: HTLV-1, Gene polymorphisms, HAM/TSP

Posted Date: August 3rd, 2020

DOl: https://doi.org/10.21203/rs.3.rs-21227/v2

License: (9) This work is licensed under a Creative Commons Attribution 4.0 International License.

Read Full License 
Version of Record: A version of this preprint was published at Journal of NeuroVirology on March 2nd, 2021. See the published version at https://doi.org/10.1007/s13365-021-00946-4. 
The authors have withdrawn this preprint from Research Square 